IZA DP No. 8233

The Effect of Islamic Secondary School Attendance on Academic Achievement

M. Niaz Asadullah

June 2014 


\title{
The Effect of Islamic Secondary School Attendance on Academic Achievement
}

\author{
M. Niaz Asadullah \\ University of Malaya, University of Reading, \\ SKOPE, University of Oxford and IZA
}

Discussion Paper No. 8233

June 2014

IZA
P.O. Box 7240
53072 Bonn
Germany

Phone: +49-228-3894-0

Fax: +49-228-3894-180

E-mail: iza@iza.org

\begin{abstract}
Any opinions expressed here are those of the author(s) and not those of IZA. Research published in this series may include views on policy, but the institute itself takes no institutional policy positions. The IZA research network is committed to the IZA Guiding Principles of Research Integrity.

The Institute for the Study of Labor (IZA) in Bonn is a local and virtual international research center and a place of communication between science, politics and business. IZA is an independent nonprofit organization supported by Deutsche Post Foundation. The center is associated with the University of Bonn and offers a stimulating research environment through its international network, workshops and conferences, data service, project support, research visits and doctoral program. IZA engages in (i) original and internationally competitive research in all fields of labor economics, (ii) development of policy concepts, and (iii) dissemination of research results and concepts to the interested public.
\end{abstract}

IZA Discussion Papers often represent preliminary work and are circulated to encourage discussion. Citation of such a paper should account for its provisional character. A revised version may be available directly from the author. 


\section{ABSTRACT \\ The Effect of Islamic Secondary School Attendance on Academic Achievement ${ }^{*}$}

Using unique survey data on rural secondary school children, this paper evaluates the relative quality of Islamic secondary schools (i.e. madrasahs) in Bangladesh. Students attending registered madrasahs fare worse in maths and English than students attending non-madrasah schools. However, failure to account for non-random sorting over-estimates the negative influence of madrasahs on student achievement. Evidence on the magnitude of this bias is presented. Once selection effect is taken into account, madrasah disadvantage in English is small while that in maths becomes insignificant. Given the overall low level of achievement, this suggests that madrasah students perform just as poorly as those from nonmadrasah schools in rural Bangladesh.

JEL Classification: D04, I21, O15

Keywords: instrumental variable, madrasahs, school quality, Bangladesh

Corresponding author:

M Niaz Asadullah

Centre for Poverty and Development Studies (CPDS)

Faculty of Economics and Administration

Malaya University

Kuala Lumpur 50603

Malaysia

E-mail: m.niaz@um.edu.my

\footnotetext{
* I gratefully acknowledge financial support from the Leverhulme Trust UK. The first draft of the paper was written when I was visiting the Research and Evaluation Division (RED) of BRAC as a Distinguished Fellow. I would like to thank Todd Elder for help with STATA codes used in the empirical analysis and Zihad Hassan of DATA who managed the survey work with utmost professional competence.
} 


\section{Introduction}

How to improve student learning in developing as well as developed countries is a hotly debated issue in the economics literature. On the basis of the research over the past two decades, the emerging consensus is that resources do not have a systematic impact on student achievement - evidence is growing against resource-based educational interventions (Hanushek, 2003; Hanushek and Woessmann, 2008). Increasingly, governments are favouring policies based on incentives, governance, increased choice and competition. In this context, the current focus is on identifying institutional features that are correlated with good governance and accountability. One such institutional correlate is faith orientation of the school. Some argue that faith (e.g. Catholic) schools in developed countries are managed by intrinsically motivated educators and follow pedagogic practices that give students a unique learning advantage over their non-faith schooled peers (e.g. see Evans and Schwab, 1995; Sander, 1996; Neal, 1997; Prais, 2005).

Faith schools are not unique to the western education system. In countries with large Muslim populations, there is a significant presence of Islamic schools (aka madrasahs). However, in Indonesia, Malaysia, India, Pakistan, and Bangladesh, madrasahs are accused of encouraging religious militancy and promoting extremism (Griswold, 2005; Bachelard, 2012; Hwang, 2012). The transnational terrorist organization, Jemaah Islamiyah (JI), allegedly benefits from madrasah networks in Thailand, Singapore, Malaysia and the Philippines. Accounts of the 2002 Bali bombers attribute their radicalization to radical madrasah attendance (Neighbour, 2004). Yet research is limited on private gains from Islamic school attendance in South and East Asia. Common perception is that madrasah schooling traps individuals into poverty. Indeed analysis of available labour market data for Bangladesh is 
suggestive of a negative correlation between religious education and wage earnings (Asadullah, 2009).

Because of concerns over madrasah quality, there are frequent calls for reform of the madrasah system in South and East Asia. However, a hitherto ignored fact in the on-going international debate is that a significant proportion of madrasahs operating in Indonesia, Malaysia and Bangladesh are already under state control. These seminaries are regulated and financed by the government and teach modern subjects such as maths, English and science. They also charge lower fees and can play an important role in improving educational access in poor communities. Nonetheless, teachers in these madrasahs often lack formal training. Moreover, religion related subjects retain a larger share in the curriculum. These deficiencies together with an emphasis on the memorization of religious texts mean that even students of government-recognized madrasahs may lag behind their peers from non-madrasah schools in terms of literacy and numeracy skills. In other words, these "reformed" madrasahs do not offer a learning advantage similar to that enjoyed by faith schools in the US and elsewhere. ${ }^{1}$

However, the negative association between madrasah attendance and test scores could be explained by the fact that these schools are disproportionately attended by children from relatively disadvantaged backgrounds. Non-random sorting of children into Islamic faith schools by family background and cognitive ability together can give rise to a negative correlation between madrasah attendance and test scores. Indeed, the possibility of non-random sorting into religious schools has been at

\footnotetext{
${ }^{1}$ Developing country studies on the performance of faith school is rare. One exception is Wodon (2013) which uses survey data from 16 countries from sub-Saharan Africa. Two findings are noteworthy: (i) faith-inspired and private non-religious schools have higher satisfaction rates among parents than government schools and (ii) students in faith and private schools perform better than those in government schools.
} 
the centre of the current debate over superiority of Catholic schools in the US. Many argue that the positive catholic school effect is largely attributed to better pupils or children from better socio-economic backgrounds. In other words, in contrast to observed negative effect of madrasah education, non-Muslim faith (e.g. Catholic) school effect is biased upward in the raw data.

To account for possible selection effect, researchers have used nonexperimental source of variation in the assignment to faith school in the US (e.g. see Evans and Schwab, 1995; Sander, 1996; Neal, 1997). However, this practice of using religious characteristics of the family or residential neighbourhood has been questioned by researchers. In two influential studies, Altonji, Elder and Taber (2005a, 2005b) argue that observed characteristics of the student do not provide valid source of identification. Altonji, Elder and Taber (henceforth AET) instead propose a novel approach to model selection effects. They argue that under certain circumstances, amount of selection on the observed explanatory variables in a model provides a guide to the amount of selection on the unobservables. It is then possible to estimate the amount of bias in the naïve Ordinary Least Squares (OLS) estimate of faith school attendance owing to unobserved characteristics of the student. Revised estimates of Catholic school effect obtained by Altonji, Elder and Taber do not suggest a positive impact on learning outcomes. More recent research also rejects the claim in favour of a positive causal relationship between faith schools attendance and learning outcomes in the UK (Gibbons and Silva, 2011) and the US (Gihleb and Giuntella, 2013; Elder and Jepsen, 2014).

The objective of this study is to evaluate the quality of registered madrasahs in rural Bangladesh in terms of student achievement. We take advantage of data from a very detailed cross-sectional survey on madrasahs that was carried out by the author. 
Our rich dataset permits superior control for student-specific un-observed correlate of learning. In addition, we argue that characteristics of place of residence (such as availability of alternatives to registered madrasahs) are not necessarily a poor instrument in rural Bangladesh where residential sorting on the basis of school availability is limited. Therefore, we report OLS as well instrumental variable (IV) estimates of the effect of madrasah attendance in mathematics and English tests. Lastly, we build on the methodology proposed by AET and report the size of potential bias in OLS estimates.

The rest of the paper is organized as follows. Section 2 explains the Bangladeshi education system with a focus on madrasahs. Section 3 describes the methodology while section 4 describes the dataset used in this study. Section 5 presents the results. Section 6 concludes by spelling out the policy implication of our findings.

\section{Study Background}

Secondary education in Bangladesh spans grades 6 to 10, and is under the purview of the Ministry of Education (MOE). In 2003, there were 8,407 registered Madrasahs (at post-primary) level against 17,389 secondary schools in the country. Bangladesh has pursued a service delivery strategy in the secondary education sector which combines a Public-Private-Partnership (PPP) model by combining public financing with private provision. Given the historical continuity of this policy strategy (through British and Pakistan periods as well), it is not surprising that the secondary education sector is dominated by registered aided non-government schools. These aided non-government schools and madrasahs accounted for 98\% of the secondary enrollment share in 2003 
(BANBEIS census 2004). ${ }^{2}$ While 81 percent of the share of secondary enrollment is in non-religious aided non-government schools (henceforth referred to as "schools”), 17 percent of the enrollment share is in registered aided non-government madrasahs. ${ }^{3}$ In registered non-government schools and madrasahs, public financing is provided primarily in the form of teacher salary where the government fully funds at least 9 teachers per institution. Since teacher salary is essentially covered by the government, government aided schools are supposed to charge a nominal tuition fee to pupils.

Madrasah secondary schools in Bangladesh are almost entirely in the non-state sector. Moreover, majority of the state-registered madrasahs also benefit fiscally from the state under the PPP model. Little systematic information is available on madrasahs that are unregistered. There is a perceived difference between registered and unregistered madrasahs in terms of in-school management practices and content of the curriculum used. These unregistered madrasahs are also known as Quomi madrasahs and operate completely outside the state sector. Education provided in unregistered madrasas is not comparable to that in registered schools and madrasahs. There is no uniform curriculum in place: share of religious education in Quomi curriculum can vary between $50 \%$ and $100 \%$ (World Bank, 2010). For this reason, our study focuses on the quality of registered madrasahs (also known as “Aliyah”) and compares this to non-madrasah schools.

The establishment of registered madrasahs and their activities follow government regulations as prescribed by the Madrasah Education Board. The Board approves curriculum for all registered madrasahs from primary to Masters level.

\footnotetext{
${ }^{2}$ Together, these two categories cater to majority of secondary school going children in Bangladesh. However, in urban areas, there are additional providers such as high fee charging private schools. Many of these schools use their own curriculum and hence are not directly comparable to registered non-religious aided schools and madrasahs. Besides, there exact number is also unknown.

${ }^{3}$ Clearly, the registered madrasah sector in Bangladesh is very large in size when compared to India and Pakistan. In contrast, Madrasahs in Pakistan account for less than 1\% of total school enrolment.
} 
These madrasahs offer a hybrid education where students are taught subjects similar to those in non-madrasah schools in addition to a curriculum of religious science and Arabic studies. In other words, in addition to Bengali, general mathematics, social science, general science, English and Arabic, students are taught Quran, Hadith and Aqaid and Fiqh.

The secondary level of registered madrasah stream is known as Dakhil which spans grades 6-10. Similar to non-madrasah education system, students appear in a public examination at the end of Dakhil education which is organized by the Bangladesh Madrasah Education Board. The Dakhil certificate is equivalent to the Secondary School Certificate (SSC) obtained after successful completion of secondary education from non-madrasah schools. There are four Dakhil madrasah curriculum groupings allowing students the option to specialize in religious and nonreligious education. Similarly, students in non-madrasah secondary schools can opt for different group specializations such as science, arts and commerce. However, they cannot specialise in religious studies. This is despite the fact that in up to grade 8 , Muslim students in non-madrasah schools are taught Islamic studies on a compulsory basis. $^{4}$ Therefore, in comparison to non-madrasah schools, registered secondary madrasahs offer students the option to specialise in general stream as well as Islamic theology. ${ }^{5}$

The root of registered madrasahs goes back to a unique event during the British Raj as well. Governor Warren Hasting of Bengal established the first registered madrasah, initially known as the Calcutta madrasah in 1781. The madrasah

\footnotetext{
${ }^{4}$ This means that $10 \%$ of the curriculum in non-madrasah school up to grade 8 comprises of lessons on religious matters. On the other hand, share of religion related matters in registered madrasahs in grade 8 is $50 \%$.

${ }^{5}$ Despite these differences, madrasahs are routinely compared with non-religious schools around the world by policy makers and political commentators. It's because of the fact that every year registered madrasah graduates compete with their peers from non-religious schools for government and private sector jobs which require knowledge of English and mathematics.
} 
taught both religious and non-religious subjects, and was supposed to be a model for madrasah reform for the rest of India. After the India-Pakistan partition, the Calcutta Aliyah madrasah was transferred to Dhaka. The registered madrasa sector started to expand in Bangladesh in the 1980s in response to a series of reform measures initiated by the government. In the early 1980s the government introduced financial incentives to madrasahs: if the madrasahs registered and introduced modern courses alongside religious subjects, then the state covered a significant portion of teacher salary. Later on an additional financial incentive was tied to increasing the share of female students (this incentive was offered to both madrasah and non-madrasah schools). Drawing upon administrative data, Asadullah and Chaudhury (2009) show that the impact of financial incentives offered by the government was significant. A large number of madrasahs opted to modernise curriculum in response to the government scheme.

Despite the mushrooming of government subsidized registered secondary madrasahs, we know little about the quality of these schools. Two findings are noteworthy from an earlier field-based research (Asadullah et al. 2007) on mathematics leaning in registered madrasah and non-madrasah high schools. First, madrasah students have lower test scores in mathematics compared to those in nonmadrasah schools. However, once we account for selection into a given school type, there is no significant learning differences across Islamic and non-madrasah schools. Second, the level of learning (measured in terms of maths skills) in general is very low. Mathematics competency is low even when measured in terms of primary standard maths test. The present study differs from Asadullah et al. (2007) in two respects. First, in addition to mathematics test scores, we assess student achievement by using data on test scores in English. Second, we use unique data on student- 
specific attributes that are otherwise unobserved to the researcher and are a common source of endogeneity bias.

\section{Empirical Strategy}

We begin by specifying a simple OLS regression model of student test scores where we control for the child's characteristics (age and gender), family background (father's education, mother's education, household wealth index and newspaper at home) and region dummies. The model also includes a dummy indicating madrasah attendance, the main variable of interest. The challenge in evaluating the quality of madrasah education using such educational production approach lies in addressing the sources of selection bias. There are at least two sources of endogeneity here. First, madrasahs are popularly perceived to impart education in an environment where strict disciplinary standard is maintained. If true, children who are considered as disruptive by parents are more likely to be enrolled in madrasahs. This causes an omitted variable problem when estimating the production function since available survey data on test scores and students in developing countries rarely contain information on disruptive behaviour and related personality traits. Second, children attending madrasahs are often from economically disadvantaged backgrounds (Asadullah, Chakrabarti and Chaudhury, Forthcoming). If true, both of these factors are likely to cause downward bias in the OLS estimate of madrasah effect.

In order to address the first problem, we expand the regression model by sequentially adding two controls that potentially capture student-specific unobservables: (a) the extent to which the child is integrated in school and (b) learning effort of the student (we explain the relevant statistical measures in the next section). The regression model conditions on household wealth thereby reducing scope for selection bias owing to family background. However, our controls for 
family background are based on self-reported data and hence, likely to be measured with error. Therefore, even after unique controls for student-specific attributes which are otherwise rarely available in developing country datasets, our OLS estimate of madrasah effect may remain downward biased (i.e. likely to be a bigger negative). For this reason, we re-estimate the achievement regression model using IV technique. As pointed out earlier, in the US literature on Catholic schools, researchers have used information on family religion, neighbours' religion and other characteristics of place of residence as excluded instruments. ${ }^{6}$ However, validity of these variables as excluded instruments have been criticised for several reasons. A common source of identification is religion (whether Catholic or not) of the child. However, being Catholic is also correlated with characteristics of the neighbourhood and family that influence the effectiveness of schools. Similarly, households choose their neighbourhoods in the US so that local availability of alternatives to faith school is not a valid instrument. However, this need not be true in rural Bangladesh where residential mobility is limited. If so, local supply of schools can be used as an exogenous determinant of madrasah attendance. Therefore, we use number of nonmadrasah schools and unregistered madrasahs as an instrument for registered madrasah attendance. ${ }^{7}$ These variables are excluded from achievement regression and assumed orthogonal to the unobserved test scores component. (i.e. residual in the achievement regression). This strategy is similar to Newhouse and Beegle (2006) who use data on the percentage of public schools in the district that the student attended public school as an instrument for public school attendance.

\footnotetext{
${ }^{6}$ Evans and Schwab (1995) use affiliation with the Catholic Church while Neal (1997) uses geographic characteristics -- proximity to Catholic schools and the fraction of Catholics in the county population as excluded instruments.

${ }^{7}$ One could think of religious affiliation of the child (e.g. whether Hindu) to model selection in madrasahs. However, unlike Catholic schools that admit students of all faith, madrasahs in Bangladesh are largely a preserve for Muslim students.
} 
One can however argue against using local availability of alternative school types as an instrument on the basis that these capture the effect of other local public goods that independently matter for student achievement. In order to deal with localarea specific unobservables, we fully control for region dummies. Moreover, we only report the IV estimates for illustrative purposes. Our main results are based on OLS estimates where for each estimate of madrasah effect, we additionally report the extent of bias following the AET approach.

In the OLS framework, the coefficient on madrasah dummy can only be consistently estimated under the restrictive conditional independence assumption (conditional on the observables) i.e. the correlation coefficient, $\rho$, between madrasah dummy and the error term is zero. Despite using a detailed specification, our regression model may suffer from omitted variable bias implying that $\rho \neq 0$. Similarly, IV estimates could be biased if the excluded instruments pick up the effect of unobservables. The AET approach helps assess sensitivity of our estimates to such bias by allowing $\rho$ to vary between 0 and 1 . This way, we can specify the covariance pattern between unobservables in the selection and the outcome equation and assess the sensitivity of the outcome coefficient of interest with increasing influence of unobservables. Under the AET approach, a particular value for $\rho$ is used under an assumption that they ensure equality of selection on unobservables and observables. The underlying idea is to ask the following question - given that the assumption of independence of unobservables assumption is likely to be violated, how large would the bias from selection on unobservables be, if that selection is in the same order as the selection on observables. According to AET approach, it is considered reasonable to view the case of equality of selection on unobservables and observables as an upper bound of the bias that is due to selection. It is assumed that the set of observable 
variables is randomly picked from the full set of variables and that, as a result, the variables that are unobserved explain just as much of the selection as the observed indicators. In practice, we would expect that researchers only gather data on observables specific to their analysis. Therefore, it is reasonable to say that we have succeeded in including observables in the analysis that explain at least as much as unobservables. This assumption makes it possible to obtain an estimate for the unobservable term, covariance between error term and madrasah dummy, under equality of selection, which in turn is used directly to estimate the bias in the OLS/IV.

\section{Survey Design and Data}

A specifically designed large education institution and household based sample survey, "Quality of Secondary School Madrasah Education in Bangladesh" (QSSMEB) was initiated by the World Bank in 2008 to primarily address the quality of education in public-aided secondary school madrasahs. The survey was designed by the authors. We randomly selected 12 districts from 6 divisions (highest administrative unit in Bangladesh). The probability proportional to size (PPS) method of random sampling was used, based on division/district level secondary school going age population data from the 2001 national population census and the concentration of secondary schools and madrasahs based on BANBEIS website 2007. Two upazilas (sub-districts) were randomly selected using PPS from each of the selected 12 districts. Then 2 unions $^{8}$ were randomly selected with PPS from each of the selected 24 upazilas. Again, the population weight was union level population data from the 2001 national population census.

In each union, a full (basic) census of all pre-primary, primary, and secondary education institutions was carried out. It is noteworthy that in the rare event when

\footnotetext{
${ }^{8}$ Union is an administrative unit in Bangladesh. It is smaller than a sub-district but bigger than a village.
} 
institutions attended by children in a sample union were outside our original sample union, we also covered those secondary schools and madrasahs located in neighbouring unions. Then, a detailed survey of all secondary educational institutions was conducted. In each sample school, we administered four distinct cognitive tests to $8^{\text {th }}$ grade students during the institutional survey ${ }^{9}$. First, a mathematics test instrument was constructed by using 25 items previously used in the Trends in International Mathematics and Science Study (TIMSS). On the basis of the national curriculum we devised a test to assess proficiency in English (20 items), General Knowledge (6 items) and Islamic studies (10 items). The test on Islamic studies, however, was restricted to Muslims only.

A unique aspect of QSSMEB survey is the coverage of all types of educational institutions. Alongside schools and registered madrasahs, we also collected complete information on all unregistered secondary madrasahs in the study area. This led to a total of 401 secondary educational institutions of which 30\% (19\%) are registered (unregistered) madrasahs. However, as pointed out earlier, unregistered madrasah education is organized following a pedagogic structure that is very different from registered schools and madrasahs. Therefore, it is difficult to identify $8^{\text {th }}$ grade equivalence in unregistered madrasahs. The other and the most important reason for non-comparability is the lack of single, uniform curriculum. These madrasahs in our sample were found to be regulated by as many as 7 different regional bodies which may explain significant regional variation in the presence of a curriculum inclusive of modern subjects such as mathematics and English (e.g. only $43.7 \%$ of the madrasahs reported teaching mathematics in grade 8 “equivalent”). For these two reasons, unregistered madrasahs have been excluded from the analysis. We argue that the

\footnotetext{
${ }^{9}$ The QSSMEB survey also had a household component. However data from this component is not used in this paper; it is the basis of a companion paper on religious school choice in rural Bangladesh (Asadullah et al, Forthcoming).
} 
exclusion of unregistered madrasahs does not lead to any selection problem. Graduates of these madrasahs are not eligible for government jobs so that the education imparted in unregistered madrasahs is not a substitute to that provided in registered madrasahs. Besides, according to QSSMEB data, unregistered madrasahs have a slightly higher share, only little over $2 \%$ of the total secondary enrolment is in these madrasahs whereas registered madrasahs boost an enrolment share of almost 19\% (Asadullah and Chaudhury, Forthcoming).

Apart from being tested in four subjects, students also completed a detailed questionnaire on their well-being at school, satisfaction with teachers, socio-economic conditions of their households and parental characteristics. In order to measure degree of student integration at school, we adopted two questions from Rosenberg selfesteem indicators (Rosenberg, 1979). In addition, the head teacher completed a questionnaire to provide information on various aspects of the school and basic background information on all the teachers. Lastly, mathematics and English teachers completed two separate questionnaires. One provided information on classroom practices and conducts of the subject teacher. The other provided a subjective assessment of each sample grade 8 student by the teacher in matters such as disruptive behavior in the classroom, late coming to class, timely completion of homework, inattentiveness, being passive, extent of truancy and performing below merit (see Appendix Table 2 for details). Responses to some of these questions were used to measure student effort. This evaluation exercise is adapted from the US National Educational Longitudinal Study (NELS). ${ }^{10}$

\footnotetext{
${ }^{10}$ These data have been used in a variety of ways in economics research, with some researchers using the data to model student personality or disruptive behaviour while others using it as some measure of non-cognitive skills.
} 
Table 1: Summary statistics by school type

\section{Student test scores \\ Maths \\ English \\ Religion \\ General knowledge}

Student background

Female

Age

Mother's education: primary

Mother's education: some secondary

Mother's education: secondary completed

Mother's education: post-secondary

Father's education: primary

Father's education: some secondary

Father's education: secondary completed

Father's education: post-secondary

Newspaper at home

\# of household assets

\# of total farm animals

Student feeling unpopular

Student being upset

Student effort (score obtained from English teacher)

Student effort (score obtained from Maths teacher)

\begin{tabular}{|c|c|c|c|c|}
\hline & ool & & Arasah & \\
\hline Mean & $\begin{array}{l}\text { Standard } \\
\text { deviation }\end{array}$ & Mean & $\begin{array}{l}\text { Standard } \\
\text { deviation }\end{array}$ & $\begin{array}{c}\text { t-test of } \\
\text { significance }\end{array}$ \\
\hline
\end{tabular}

\begin{tabular}{ccccc}
35.75 & 14.44 & 33.14 & 15.84 & Yes* \\
37.12 & 19.30 & 26.69 & 16.70 & Yes* \\
70.17 & 20.92 & 81.54 & 19.84 & Yes* \\
38.59 & 20.50 & 38.52 & 20.27 & No \\
& & & & \\
0.61 & 0.49 & 0.65 & 0.48 & Yes* \\
13.04 & 0.95 & 13.34 & 1.16 & Yes* \\
0.18 & 0.39 & 0.20 & 0.40 & No \\
0.17 & 0.37 & 0.17 & 0.37 & No \\
0.13 & 0.34 & 0.12 & 0.32 & Yes** \\
0.08 & 0.26 & 0.04 & 0.19 & Yes* \\
0.12 & 0.32 & 0.13 & 0.33 & No \\
0.17 & 0.38 & 0.17 & 0.37 & No \\
0.16 & 0.36 & 0.16 & 0.37 & No \\
0.19 & 0.39 & 0.14 & 0.35 & Yes* \\
0.39 & 0.49 & 0.33 & 0.47 & Yes* \\
0.39 & 0.19 & 0.35 & 0.18 & Yes* \\
2.26 & 2.58 & 2.38 & 2.55 & Yes** \\
0.25 & 0.43 & 0.18 & 0.38 & Yes* \\
0.25 & 0.43 & 0.23 & 0.42 & Yes* \\
-1.78 & 1.95 & -1.59 & 1.83 & Yes* \\
-1.63 & 1.87 & -1.49 & 1.73 & Yes* \\
\hline 6306 & & 2322 & & \\
\hline
\end{tabular}

Notes: (a) omitted category for mother's/father's education is “less than primary schooling completed”; (b) *and ** indicates significance at $1 \%$ and $5 \%$ level respectively.

Our main sample comprises of 9,311 pupils in Grade 8 where 73\% (27\%) of the students belong to school (registered madrasah). Table 1 presents summary statistics of the regression variables. From the Table, two differences between school and madrasah students are evident. First, school students have superior socio-economic background. They belong to more educated parents (e.g. post-secondary education of mother and father) and live in households that are wealthier and more likely to have newspapers. This suggests that madrasahs are likely to suffer from a negative selection bias. Second, learning outcomes differ across school types. While madrasah students have lower scores in maths and English tests, they appear to perform better in Religion test then their peers in non-religious schools. However, irrespective of 
school type, the level of learning remains very low. ${ }^{11}$ For instance, only $35 \%$ of the test items in mathematics could be answered correctly by our sample students. At the same time, learning difference between students of non-madrasah schools and madrasahs in mathematics is only 2 percentage points. Our sample average maths score is strikingly similar to mean student performance in similar tests for secondary school students elsewhere in South Asia. For instance, in a recent study on two Indian states Orissa and Rajasthan, Das and Zajonc (2010) report mean scores (i.e. \% correct answer) of 34 and 37 respectively. Their findings are based on a survey of $9^{\text {th }}$ grade students in mathematics carried out in the year 2005 using a 36-item TIMSS test.

The average number of correctly answered questions is even lower (i.e. 33\%) for English. However, the school-madrasah gap in test scores is much larger -- 9 percentage points. When compared by gender, females have lower scores. However, this is true for both school and madrasah sample- the advantage of non-madrasah school is an across-gender phenomenon. However, irrespective of the test subject, boy-girl difference in test scores is largest in madrasahs. Interestingly, the performance is far from satisfactory even if we consider performance in the general knowledge test: only 39\% of the questions were correctly answered on average. However, when assessed in matters related to religion (i.e. Islam), the performance was very satisfactory: students on average correctly answered $75 \%$ of all the test items. $^{12}$

\footnotetext{
${ }^{11}$ This is also consistent with previous assessment of rural schools employing TIMSS question items in Bangladesh (Asadullah, Chaudhury and Dar, 2007) and India (Das and Zajonc, 2010). The percentage of correct answers ranged between $36 \%$ and $38 \%$. Das and Zajonc focused on secondary school students from two Indian states--Orissa and Rajasthan. This confirms that the level of learning is very low in secondary grades in Bangladesh and is not owing to employing a relatively hard assessment questionnaire.

${ }^{12}$ From the figures on the fraction of correct answers in different subjects, it is not obvious whether the questions have been set at a reasonable degree of difficulty. The state of poor-quality becomes even more evident if we consider few examples of student performance in individual questions where a majority of students were unable to answer. For instance, let us focus on two simple questions related to division and fractions. Only $62 \%$ of school students and 54\% of Aliyah students could correctly
} 
Additional information relating to characteristics of the sample schools and teachers across for sample institutions are presented in Appendix Table 1. Several institutional differences between school and madrasah students are evident. Differences in curriculum and student test performance aside, registered schools and madrasahs differ significantly in terms of costs and physical inputs. On average, schools have a bigger land area, are better inspected by the government and have a larger proportion of trained teachers. They also charge higher fees and pay a higher salary to their teachers. Schools also have more female and better educated teachers. However, in terms of hours spent in lesson preparation, there is no difference between madrasah and school teachers. These institutional and teacher-specific differences may interact with student background to give rise to learning gaps between school and madrasah students. We explore this issue formally in the next section.

\section{Main Results}

As mentioned earlier, we begin by estimating a simple OLS regression model of student achievement where we control for the child's characteristics (age and gender), family background (father's education, mother's education, household wealth index and newspaper at home), madrasah attendance status and region dummies (see Tables 2 and 3). In order to make the test scores in maths and English comparable, we standardize the scores in each subject by the sample mean mark in the subject and create the z-scores of achievement as our dependent variable. The $\mathrm{z}$-score is a student's mark in a subject less the overall mean mark in that subject in our dataset, divided by the standard deviation of mark in the subject. Therefore, by construction,

answer the following question: "Divide: $\frac{8}{35} \div \frac{4}{15}$ ”. By $8^{\text {th }}$ grade, only $11 \%$ of school children and $8 \%$ of Aliyah children can correctly divide 24.56 by 0.004 . A simple measurement test "Which of these is the longest time? \{(a) 15000 seconds (b) 1500 minutes (c) 10 hours (d) 1 day\}" is too difficult for 46\% of grade 8 children in our sample. When disaggregated by institution type, only $56 \%$ and $51 \%$ of the school and Aliyah students, respectively, could correctly answer the question. 
mean z-scores in any given subject is 0 and its standard deviation is 1 . Appendix Figure 1 shows the distribution of raw data and z-scores for maths and English.

The key innovation in our study is the availability of data on self-esteem, personality traits and disruptive behaviour of students. These are important unobservable student-specific attributes that may matter for learning outcomes. Their exclusion can cause an omitted variable bias in the estimated coefficient on madrasah dummy. Therefore, we also present OLS estimates of educational production function where controls for self-esteem and an aggregate measure of student effort are introduced in a sequential manner (see models 2 and 3, Tables 2 and 3). All the covariates in Tables 2 and 3 have the expected sign. For instance, irrespective of the test subject, girls score less than boys, children from well-off families (i.e. higher household wealth) score higher and children of educated parents also have high test scores. It is worth assessing the role of two sets of variables that we argue capture student-specific unobservables.

The first two variables - student feeling unpopular and student being upset are measures of integration in school. If the social distance between the student and her peers in school is large, this can cause psychic distress and in turn lower scholastic achievement (Akerlof and Kranton, 2002). Indeed, the coefficients on these variables are always negative although at times insignificant. The other set of variables that enter in an aggregate form in the model is teacher's personal evaluation of the student's effort in learning. As was pointed out earlier, we use a set of 7 indicators to assess student effort which where adapted from the US NELS questionnaire (for details, see Appendix Table 2). The subject teacher rates students using these 7 indicators (with respect to the student's behaviour in lessons specific to the subject) which we then add up by using weights derived from factor analysis. To measure 
student effort, we took the negative of the aggregated score. The coefficient on the resultant variable in Tables 2 and 3 is always significant and positive. In the pooled sample, it increases mathematics (English) score by $0.06(0.10)$ of a standard deviation. 
Table 2: OLS estimates of determinants of mathematics test scores

\begin{tabular}{|c|c|c|c|c|c|c|c|c|c|}
\hline & Full & Full & Full & Male & Male & Male & Female & Female & Female \\
\hline & (1) & (2) & (3) & (1) & (2) & (3) & (1) & (2) & (3) \\
\hline \multirow[t]{2}{*}{ Madrasah } & -0.145 & -0.155 & -0.166 & -0.112 & -0.112 & -0.123 & -0.156 & -0.170 & -0.182 \\
\hline & $(6.17)^{* *}$ & $(6.56)^{* *}$ & $(7.08)^{* *}$ & $(2.86)^{* *}$ & $(2.86)^{* *}$ & $(3.16)^{* *}$ & $(5.32)^{* *}$ & $(5.77)^{* *}$ & $(6.22)^{* *}$ \\
\hline \multirow[t]{2}{*}{ Female } & -0.349 & -0.350 & -0.346 & & & & & & \\
\hline & $(17.11)^{* *}$ & $(17.19)^{* *}$ & $(17.09)^{* *}$ & & & & & & \\
\hline \multirow[t]{2}{*}{ Child's age } & -0.091 & -0.073 & -0.062 & -0.359 & -0.343 & -0.315 & 0.163 & 0.181 & 0.167 \\
\hline & $(0.77)$ & $(0.62)$ & $(0.53)$ & (2.26)* & $(2.16)^{*}$ & $(2.00)^{*}$ & $(0.91)$ & $(1.01)$ & $(0.93)$ \\
\hline \multirow[t]{2}{*}{ Child's age (squared) } & 0.002 & 0.001 & 0.001 & 0.011 & 0.011 & 0.010 & -0.008 & -0.008 & -0.008 \\
\hline & $(0.39)$ & $(0.24)$ & $(0.18)$ & $(1.94)^{+}+$ & $(1.85)^{+}$ & $(1.73)^{+}$ & $(1.14)$ & $(1.24)$ & (1.16) \\
\hline \multirow[t]{2}{*}{ Non-Muslim } & -0.040 & -0.039 & -0.042 & -0.118 & -0.118 & -0.119 & 0.023 & 0.025 & 0.022 \\
\hline & (1.03) & $(1.00)$ & (1.09) & $(2.08) *$ & $(2.10)^{*}$ & $(2.12)^{*}$ & $(0.44)$ & $(0.49)$ & $(0.42)$ \\
\hline \multirow[t]{2}{*}{ Mother's education: primary } & 0.068 & 0.064 & 0.060 & 0.080 & 0.072 & 0.072 & 0.073 & 0.071 & 0.063 \\
\hline & $(2.40)^{*}$ & $(2.26)^{*}$ & $(2.13)^{*}$ & $(1.75)^{+}$ & (1.59) & $(1.60)$ & $(2.05)^{*}$ & $(2.01)^{*}$ & $(1.79)^{+}$ \\
\hline \multirow[t]{2}{*}{ Mother's education: some secondary } & 0.075 & 0.074 & 0.070 & 0.051 & 0.046 & 0.054 & 0.095 & 0.095 & 0.084 \\
\hline & $(2.51)^{*}$ & $(2.49) *$ & $(2.35)^{*}$ & $(1.02)$ & $(0.92)$ & (1.09) & $(2.56)^{*}$ & $(2.59)^{* *}$ & $(2.31)^{*}$ \\
\hline \multirow[t]{2}{*}{ Mother's education: secondary completed } & 0.068 & 0.068 & 0.072 & 0.028 & 0.022 & 0.030 & 0.089 & 0.092 & 0.094 \\
\hline & $(1.97)^{*}$ & $(1.98)^{*}$ & $(2.11)^{*}$ & $(0.51)$ & $(0.40)$ & $(0.55)$ & $(2.05)^{*}$ & $(2.15)^{*}$ & $(2.20)^{*}$ \\
\hline \multirow[t]{2}{*}{ Mother's education: post-secondary } & 0.144 & 0.149 & 0.136 & 0.110 & 0.108 & 0.103 & 0.160 & 0.170 & 0.155 \\
\hline & $(3.18)^{* *}$ & $(3.31)^{* *}$ & $(3.05)^{* *}$ & (1.56) & (1.54) & (1.48) & $(2.77)^{* *}$ & $(2.95)^{* *}$ & $(2.71)^{* *}$ \\
\hline \multirow[t]{2}{*}{ Father's education: primary } & 0.031 & 0.032 & 0.025 & 0.037 & 0.032 & 0.020 & 0.011 & 0.014 & 0.011 \\
\hline & $(0.93)$ & $(0.95)$ & $(0.76)$ & $(0.70)$ & $(0.60)$ & $(0.37)$ & $(0.27)$ & $(0.33)$ & $(0.27)$ \\
\hline \multirow[t]{2}{*}{ Father's education: some secondary } & 0.037 & 0.035 & 0.023 & -0.011 & -0.014 & -0.023 & 0.062 & 0.060 & 0.045 \\
\hline & $(1.24)$ & $(1.20)$ & $(0.79)$ & $(0.23)$ & $(0.28)$ & $(0.49)$ & $(1.70)^{+}$ & (1.64) & (1.24) \\
\hline \multirow[t]{2}{*}{ Father's education: secondary completed } & 0.052 & 0.046 & 0.039 & 0.044 & 0.041 & 0.030 & 0.058 & 0.053 & 0.048 \\
\hline & $(1.66)^{+}$ & $(1.50)$ & $(1.27)$ & $(0.86)$ & $(0.79)$ & $(0.59)$ & (1.51) & (1.39) & (1.25) \\
\hline \multirow[t]{2}{*}{ Father's education: post-secondary } & 0.141 & 0.136 & 0.118 & 0.135 & 0.132 & 0.116 & 0.130 & 0.125 & 0.105 \\
\hline & $(4.33)^{* *}$ & $(4.19)^{* *}$ & $(3.66)^{* *}$ & $(2.60)^{* *}$ & $(2.55)^{*}$ & $(2.25)^{*}$ & $(3.18)^{* *}$ & $(3.04)^{* *}$ & $(2.58)^{*}$ \\
\hline \multirow[t]{2}{*}{ Newspaper at home } & -0.018 & -0.020 & -0.024 & 0.054 & 0.053 & 0.045 & -0.058 & -0.062 & -0.064 \\
\hline & $(0.80)$ & $(0.89)$ & (1.11) & (1.48) & (1.46) & $(1.25)$ & $(2.09)^{*}$ & $(2.22)^{*}$ & $(2.33)^{*}$ \\
\hline \multirow[t]{2}{*}{ Household wealth index } & 0.044 & 0.045 & 0.041 & 0.026 & 0.027 & 0.024 & 0.051 & 0.051 & 0.047 \\
\hline & $(4.00)^{* *}$ & $(4.08)^{* *}$ & $(3.74)^{* *}$ & (1.46) & (1.56) & (1.38) & $(3.69)^{* *}$ & $(3.72)^{* *}$ & $(3.45)^{* *}$ \\
\hline \multirow[t]{2}{*}{ Student feeling unpopular } & & -0.101 & -0.086 & & -0.066 & -0.048 & & -0.112 & -0.098 \\
\hline & & $(4.30)^{* *}$ & $(3.68)^{* *}$ & & $(1.76)+$ & $(1.27)$ & & $(3.78)^{* *}$ & $(3.33)^{* *}$ \\
\hline \multirow[t]{2}{*}{ Student being upset } & & -0.092 & -0.087 & & -0.138 & -0.131 & & -0.071 & -0.069 \\
\hline & & $(3.96)^{* *}$ & $(3.76)^{* *}$ & & $(3.82)^{* *}$ & $(3.64)^{* *}$ & & $(2.39)^{*}$ & (2.33)* \\
\hline \multirow[t]{2}{*}{ Student effort (teacher's evaluation) } & & & 0.064 & & & 0.066 & & & 0.062 \\
\hline & & & $(11.23)^{* *}$ & & & $(7.03)^{* *}$ & & & $(8.78)^{* *}$ \\
\hline \multirow{2}{*}{ Constant } & 1.295 & 1.205 & 1.241 & 3.638 & 3.555 & 3.433 & -1.016 & -1.097 & -0.861 \\
\hline & (1.59) & (1.48) & (1.53) & $(3.24)^{* *}$ & $(3.18)^{* *}$ & $(3.09)^{* *}$ & $(0.83)$ & $(0.89)$ & $(0.71)$ \\
\hline $\mathrm{N}$ & 8483 & 8483 & 8483 & 3257 & 3257 & 3257 & 5226 & 5226 & 5226 \\
\hline R-squared & 0.20 & 0.20 & 0.21 & 0.14 & 0.14 & 0.15 & 0.24 & 0.25 & 0.26 \\
\hline
\end{tabular}

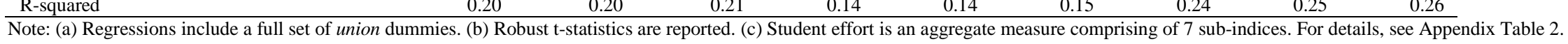


Table 3: OLS estimates of determinants of English test scores

\begin{tabular}{|c|c|c|c|c|c|c|c|c|c|}
\hline & Full & Full & Full & Male & Male & Male & Female & Female & Female \\
\hline & (1) & (2) & (3) & (1) & (2) & (3) & (1) & (2) & (3) \\
\hline \multirow{2}{*}{ Madrasah } & -0.496 & -0.509 & -0.532 & -0.460 & -0.464 & -0.487 & -0.509 & -0.529 & -0.546 \\
\hline & $(20.95)^{* *}$ & $(21.47)^{* *}$ & $(22.86) * *$ & $(11.42)^{* *}$ & $(11.49)^{* *}$ & $(12.38)^{* *}$ & $(17.51)^{* *}$ & $(18.16)^{* *}$ & $(18.99)^{* *}$ \\
\hline \multirow[t]{2}{*}{ Female } & -0.115 & -0.113 & -0.109 & & & & & & \\
\hline & $(5.63)^{* *}$ & $(5.54)^{* *}$ & $(5.42)^{* *}$ & & & & & & \\
\hline \multirow[t]{2}{*}{ Child's age } & -0.192 & -0.186 & -0.207 & -0.275 & -0.272 & -0.212 & -0.242 & -0.230 & -0.316 \\
\hline & (1.62) & (1.57) & $(1.79)^{+}$ & $(1.67)^{+}$ & $(1.66)^{+}$ & (1.34) & (1.35) & (1.29) & $(1.81)^{+}$ \\
\hline \multirow[t]{2}{*}{ Child's age (squared) } & 0.004 & 0.004 & 0.005 & 0.008 & 0.008 & 0.006 & 0.006 & 0.006 & 0.009 \\
\hline & (1.00) & $(0.96)$ & (1.24) & (1.33) & $(1.32)$ & (1.06) & $(0.92)$ & $(0.86)$ & (1.41) \\
\hline \multirow[t]{2}{*}{ Non-Muslim } & -0.054 & -0.051 & -0.068 & -0.107 & -0.106 & -0.127 & -0.005 & 0.001 & -0.010 \\
\hline & (1.39) & (1.30) & $(1.78)^{+}$ & $(1.83)^{+}$ & $(1.82)^{+}$ & $(2.25)^{*}$ & $(0.09)$ & $(0.02)$ & $(0.20)$ \\
\hline \multirow[t]{2}{*}{ Mother’s education: primary } & 0.117 & 0.113 & 0.112 & 0.133 & 0.129 & 0.129 & 0.120 & 0.119 & 0.113 \\
\hline & $(4.10)^{* *}$ & $(3.98)^{* *}$ & $(4.02)^{* *}$ & $(2.82)^{* *}$ & $(2.73)^{* *}$ & $(2.82)^{* *}$ & $(3.41)^{* *}$ & $(3.39)^{* *}$ & $(3.28)^{* *}$ \\
\hline \multirow[t]{2}{*}{ Mother's education: some secondary } & 0.127 & 0.125 & 0.125 & 0.081 & 0.079 & 0.101 & 0.172 & 0.170 & 0.161 \\
\hline & $(4.21)^{* *}$ & $(4.17)^{* *}$ & $(4.24)^{* *}$ & $(1.58)$ & (1.53) & $(2.02)^{*}$ & $(4.70)^{* *}$ & $(4.69)^{* *}$ & $(4.51)^{* *}$ \\
\hline \multirow[t]{2}{*}{ Mother's education: secondary completed } & 0.104 & 0.104 & 0.110 & 0.090 & 0.087 & 0.103 & 0.132 & 0.135 & 0.136 \\
\hline & $(3.01)^{* *}$ & $(3.01)^{* *}$ & $(3.27)^{* *}$ & (1.57) & $(1.52)$ & $(1.86)+$ & $(3.10)^{* *}$ & $(3.18)^{* *}$ & $(3.27)^{* *}$ \\
\hline \multirow[t]{2}{*}{ Mother's education: post-secondary } & 0.167 & 0.170 & 0.164 & 0.154 & 0.153 & 0.142 & 0.160 & 0.169 & 0.166 \\
\hline & $(3.68) * *$ & $(3.75) * *$ & $(3.71)^{* *}$ & $(2.12)^{*}$ & $(2.10)^{*}$ & $(2.01)^{*}$ & $(2.80)^{* *}$ & $(2.96)^{* *}$ & $(2.97)^{* *}$ \\
\hline \multirow{2}{*}{ Father’s education: primary } & 0.021 & 0.019 & 0.009 & 0.040 & 0.038 & 0.010 & 0.005 & 0.003 & 0.003 \\
\hline & $(0.62)$ & $(0.57)$ & $(0.27)$ & $(0.73)$ & $(0.70)$ & $(0.19)$ & $(0.11)$ & $(0.06)$ & $(0.06)$ \\
\hline \multirow[t]{2}{*}{ Father's education: some secondary } & 0.050 & 0.050 & 0.034 & 0.029 & 0.029 & 0.003 & 0.074 & 0.070 & 0.060 \\
\hline & $(1.69)+$ & $(1.68)+$ & $(1.17)$ & $(0.58)$ & $(0.58)$ & $(0.07)$ & $(2.02)^{*}$ & $(1.94)+$ & $(1.68)+$ \\
\hline \multirow[t]{2}{*}{ Father’s education: secondary completed } & 0.068 & 0.059 & 0.045 & 0.047 & 0.042 & 0.027 & 0.073 & 0.064 & 0.051 \\
\hline & $(2.16)^{*}$ & $(1.90)+$ & (1.46) & $(0.89)$ & $(0.80)$ & $(0.52)$ & $(1.91)^{+}$ & $(1.70)^{+}$ & (1.38) \\
\hline \multirow[t]{2}{*}{ Father's education: post-secondary } & 0.200 & 0.195 & 0.165 & 0.145 & 0.143 & 0.120 & 0.230 & 0.225 & 0.193 \\
\hline & $(6.10)^{* *}$ & $(5.98)^{* *}$ & $(5.17)^{* *}$ & $(2.70)^{* *}$ & $(2.67)^{* *}$ & $(2.31)^{*}$ & $(5.66)^{* *}$ & $(5.56)^{* *}$ & $(4.85)^{* *}$ \\
\hline \multirow[t]{2}{*}{ Newspaper at home } & 0.002 & -0.002 & -0.016 & -0.029 & -0.030 & -0.044 & 0.010 & 0.003 & -0.009 \\
\hline & $(0.07)$ & $(0.10)$ & $(0.71)$ & $(0.78)$ & $(0.81)$ & $(1.22)$ & $(0.37)$ & $(0.12)$ & $(0.35)$ \\
\hline \multirow[t]{2}{*}{ Household wealth index } & 0.031 & 0.031 & 0.022 & 0.052 & 0.052 & 0.044 & 0.015 & 0.015 & 0.008 \\
\hline & $(2.82)^{* *}$ & $(2.81)^{* *}$ & $(2.05)^{*}$ & $(2.88)^{* *}$ & $(2.89)^{* *}$ & $(2.51)^{*}$ & (1.12) & (1.09) & $(0.58)$ \\
\hline \multirow[t]{2}{*}{ Student feeling unpopular } & & -0.166 & -0.147 & & -0.073 & -0.051 & & -0.211 & -0.194 \\
\hline & & $(7.00)^{* * *}$ & $(6.33)^{* *}$ & & $(1.86)^{+}$ & (1.35) & & $(7.20)^{* *}$ & $(6.72)^{* *}$ \\
\hline \multirow[t]{2}{*}{ Student being upset } & & 0.014 & 0.016 & & -0.019 & -0.007 & & 0.028 & 0.024 \\
\hline & & (0.59) & (0.71) & & $(0.51)$ & $(0.20)$ & & $(0.95)$ & $(0.84)$ \\
\hline \multirow{2}{*}{ Student effort (teacher's evaluation) } & & & 0.104 & & & 0.128 & & & 0.088 \\
\hline & & & $(19.61)^{* *}$ & & & $(14.51)^{* *}$ & & & $(13.31)^{* *}$ \\
\hline \multirow[t]{2}{*}{ Constant } & 2.115 & 2.101 & 2.342 & 2.422 & 2.413 & 2.140 & 2.421 & 2.389 & 3.039 \\
\hline & $(2.57)^{*}$ & $(2.56)^{*}$ & $(2.92)^{* *}$ & $(2.09)^{*}$ & $(2.08)^{*}$ & $(1.91)^{+}$ & $(1.99)^{*}$ & $(1.97)^{*}$ & $(2.55)^{*}$ \\
\hline $\mathrm{N}$ & 8483 & 8483 & 8483 & 3257 & 3257 & 3257 & 5226 & 5226 & 5226 \\
\hline R-squared & 0.19 & 0.19 & 0.23 & 0.21 & 0.21 & 0.26 & 0.22 & 0.23 & 0.26 \\
\hline
\end{tabular}


In sum, Tables 2 and 3 confirm the importance of student-specific unobservable factors in educational production. Therefore, we repeat the analysis by using alternative methods of estimation. The main results are reported in Tables 4 and 5. Table 4 reports estimates of the effect of madrasah attendance on mathematics scores while the same is reported for English scores in Table 5. In addition to results for the pooled sample, we also report the estimate of madrasah attendance separately for boys and girls.

In each Table, OLS and IV are reported (first and last columns) alongside an estimate of bias in the OLS estimate (column 2). For a given estimate, a total of 3 variants are reported. The first row corresponds to estimates that are obtained from a model where we only control for the child's demographic attributes ${ }^{13}$, family background and dummies for school catchment area. The second row presents estimates that are obtained from a model where we additionally control for the extent of integration in school. Lastly, the third row for each sample presents estimates that are obtained by jointly controlling for the extent of integration in school and student effort level, in addition to the child's demographic attributes, family background and area dummies.

The first column in Tables $\mathbf{4}$ and $\mathbf{5}$ respectively report the OLS estimates of madrasah effect in mathematics and English with controls for observables (age, gender, religion, parental education and household wealth). Also included is a full set of dummies for place of residence. For the sake of brevity, we only report the coefficient on the madrasah dummy.

\footnotetext{
${ }^{13}$ In alternative specifications, we also controlled for the child's health (height for age and weight for age). However, these variables were not significant. Neither did they alter the size and significance of the point estimate of madrasah effect. Hence, they were excluded from the final model.
} 
Looking across the three model specifications used, it is unsurprising that the OLS estimate of madrasah effect changes as we bring in control for student-specific measures that are otherwise unobserved to the researcher. For instance, in the parsimonious specification with no control for "unobservables" (i.e. model 1), the madrasah effect is -0.14 of a standard deviation in mathematics (pooled sample). However, with controls for these two sets of student-specific “unobservables”, the madrasah coefficient becomes -0.16 (i.e. model 3). This sizable gain in size remains irrespective of the test subject and whether we focus on pooled sample, boys or girls. This is consistent with the fact that madrasah students are reported to be better-integrated in school and given a higher score by their teachers for their learning effort. Nonetheless, our data does not capture all other sources of unobservables such as innate ability. Madrasah students on average may be more disciplined and better-integrated yet of low ability. ${ }^{14}$ If true, this may lead to downward bias in the OLS estimates.

\footnotetext{
${ }^{14}$ As such, we are likely to under-estimate negative selection effects allowing a positive selection effect to dominate as evident from high values of effort indicators in the madrasah sample. The negative effect is present in our data (e.g., madrasah students come from poorer socio-economic status as seen from Table 1) yet underestimated along socio-economic dimension as we have poor controls for household poverty, one of the most important determinants of madrasah enrolment in rural Bangladesh (Asadullah et al., Forthcoming).
} 
Table 4: OLS and IV estimates of the effect of madrasah attendance on mathematics score

\begin{tabular}{|c|c|c|c|c|}
\hline & Regression specification & OLS & bias & IV \\
\hline \multirow[t]{6}{*}{ Full } & \multirow[t]{2}{*}{ Model 1: Personal \& family attributes, \& region dummies } & -0.145 & -0.25 & 0.082 \\
\hline & & $(6.56)^{* *}$ & 0.05 & $(0.48)$ \\
\hline & \multirow[t]{2}{*}{ Model 2: (+) Integration } & -0.155 & -0.21 & 0.104 \\
\hline & & $(6.76)^{* *}$ & 0.04 & $(0.75)$ \\
\hline & \multirow[t]{2}{*}{ Model 3: (+) Integration \& Effort/Non-cognitive ability } & -0.166 & -0.16 & 0.182 \\
\hline & & $(7.08)^{* *}$ & 0.04 & $(0.85)$ \\
\hline \multirow[t]{6}{*}{ Male } & \multirow[t]{2}{*}{ Model 1: Personal \& family attributes, \& region dummies } & -0.112 & -0.14 & -0.026 \\
\hline & & $(2.86)^{* *}$ & 0.16 & $(0.06)$ \\
\hline & \multirow[t]{2}{*}{ Model 2: (+) Integration } & -0.112 & -0.14 & 0.018 \\
\hline & & $(2.86)^{* *}$ & 0.15 & $(0.04)$ \\
\hline & \multirow[t]{2}{*}{ Model 3: (+) Integration \& Effort/ Non-cognitive ability } & -0.123 & -0.06 & 0.148 \\
\hline & & $(3.16)^{* *}$ & 0.14 & $(0.30)$ \\
\hline \multirow[t]{6}{*}{ Female } & \multirow[t]{2}{*}{ Model 1: Personal \& family attributes, \& region dummies } & -0.156 & -0.23 & 0.247 \\
\hline & & $(5.32)^{* *}$ & 0.04 & $(1.06)$ \\
\hline & \multirow[t]{2}{*}{ Model 2: $(+)$ Integration } & -0.170 & -0.19 & 0.261 \\
\hline & & $(5.77)^{* *}$ & 0.04 & $(1.13)$ \\
\hline & \multirow[t]{2}{*}{ Model 3: $(+)$ Integration \& Effort/ Non-cognitive ability } & -0.182 & -0.14 & 0.297 \\
\hline & & $(6.22)^{* *}$ & 0.04 & $(1.30)$ \\
\hline
\end{tabular}

Note: (a) Detailed regression specifications (OLS model only) are reported in Table 1. (b) Estimates of bias in OLS model is based on AET paper. (c) Excluded instruments in the IV model are number of non-madrasah schools and unregistered madrasahs in the catchment area. (d) Extent of integration is defined in terms of two variables: Student feeling unpopular and student being upset. (f) t-statistics in parenthesis.

To this end, Tables 4 and 5 also report IV estimates of madrasah effects in the third column. As excluded instruments, we use local supply of alternatives to registered madrasahs, namely number of non-madrasah schools and unregistered madrasahs. Interestingly enough, no longer is the madrasah coefficient significant. In case of mathematics regression, this is true for all sample and specifications (see Table 4). All the point estimates are also positive (except one for the male sub-sample). In case of English, however, the point estimates are always negative although all the gender-specific estimates are insignificant (see Table 5). 
Table 5: OLS and IV estimates of the effect of madrasah attendance on English score

\begin{tabular}{|c|c|c|c|c|}
\hline & Regression specification & OLS & bias & IV \\
\hline \multirow[t]{6}{*}{ Full } & \multirow[t]{2}{*}{ Model 1: Personal \& family attributes, \& region dummies } & -0.496 & -0.72 & -0.448 \\
\hline & & $(20.95)^{* *}$ & 0.08 & $(2.03)^{*}$ \\
\hline & \multirow[t]{2}{*}{ Model 2: (+) Integration } & -0.509 & -0.66 & -0.465 \\
\hline & & $(21.47)^{* *}$ & 0.08 & $(2.11)^{*}$ \\
\hline & \multirow[t]{2}{*}{ Model 3: $(+)$ Integration \& effort/ Non-cognitive ability } & -0.532 & -0.45 & -0.375 \\
\hline & & $(22.86)^{* *}$ & 0.06 & $(1.84)+$ \\
\hline \multirow[t]{6}{*}{ Male } & \multirow[t]{2}{*}{ Model 1: Personal \& family attributes, \& region dummies } & -0.460 & -0.59 & -0.569 \\
\hline & & $(11.42)^{* *}$ & 0.14 & $(1.14)$ \\
\hline & \multirow[t]{2}{*}{ Model 2: (+) Integration } & -0.464 & -0.58 & -0.605 \\
\hline & & $(11.49)^{* *}$ & 0.14 & $(1.17)$ \\
\hline & \multirow[t]{2}{*}{ Model 3: $(+)$ Integration \& effort/ Non-cognitive ability } & -0.487 & -0.38 & -0.073 \\
\hline & & $(12.38)^{* *}$ & 0.10 & $(0.15)$ \\
\hline \multirow[t]{6}{*}{ Female } & \multirow[t]{2}{*}{ Model 1: Personal \& family attributes, \& region dummies } & -0.509 & -0.70 & -0.035 \\
\hline & & $(17.51)^{* *}$ & 0.08 & $(0.15)$ \\
\hline & \multirow[t]{2}{*}{ Model 2: (+) Integration } & -0.529 & -0.54 & -0.106 \\
\hline & & $(18.42)^{* *}$ & 0.07 & $(0.49)$ \\
\hline & \multirow[t]{2}{*}{ Model 3: (+) Integration \& effort/ Non-cognitive ability } & -0.546 & -0.43 & -0.122 \\
\hline & & $(18.99)^{* *}$ & 0.06 & $(0.57)$ \\
\hline
\end{tabular}

Note: (a) Detailed regression specifications (OLS model only) are reported in Table 2. (b) Estimates of bias in OLS model is based on AET paper. (c) Excluded instruments in the IV model are number of non-madrasah schools and traditional religious schools in the catchment area. (d) Extent of integration is defined in terms of two variables: Student feeling unpopular and student being upset. (e) t-statistics in parenthesis.

The validity of the IV estimates depends on the goodness of our excluded instruments. In all our 48 sample clusters, at least $25 \%$ of the secondary educational institutions are nonreligious schools. Therefore, local availability of non-madrasah schools should have significant predictive power as an instrument. Indeed, in all the first stage regressions (results not reported but available from the authors upon request), this variable negatively (and significantly) affects the probability of enrolment in madrasahs. However, despite their availability, non-religious schools may be over-subscribed. ${ }^{15}$ Local supply of registered

\footnotetext{
${ }^{15}$ Indeed, mean class-size in grade 8 is much larger in non-madrasah schools than madrasahs in QSSMEB dataset.
} 
schools may also be correlated with other community-specific measures of student achievement. All these issues may undermine our IV estimates.

Indeed, the very large difference between OLS and IV estimates are suggestive of the possibility that IV estimates are biased. Therefore, we follow the methodology proposed by AET and use the degree of selection on observables as a guide to how much selection there is on unobservables. The resultant bias in OLS estimate is reported in Column 2. There are three main findings. First, as we introduce controls for student-specific unsobervables, the estimate of the bias is reduced in size. For instance, the estimate is reduced from -0.25 (model 1) to -0.16 (model 3) in Table 1 (full sample). Similarly, it is reduced from -0.72 (model 1) to -0.45 (model 3) in Table 2 (full sample).

Second, size of the bias in OLS model is large. For instance, in case of mathematics (full sample, specification 1), estimate of the bias is larger than the OLS estimate of madrasah effect, leading to the true effect to be positive. As a matter of fact, 10 out of 12 estimates of bias in Table 4 are equal to or larger than the corresponding OLS estimates suggesting that the true point estimate is actually positive. Similarly, 9 out of 12 estimates of bias in Table 5 are equal to or larger than the corresponding OLS estimates suggesting that the true point estimate is actually positive. However, in both Tables, estimates of bias corresponding to model 3 (our most preferred specification) is always either smaller than or equal to the OLS estimate suggesting that the true effect is either zero or a smaller negative.

Third, on the basis of our preferred model estimates, OLS estimate based on correct model specification should be a smaller negative. When compared to IV estimates, this is true for English score. But in case of mathematics score, IV point estimates are always positive 
and hence inconsistent with the bias corrected OLS estimates. For instance in Table 4, both the OLS estimate of madrasah effect and the AET measure of bias is -0.16 . Yet, the IV estimate is 0.06. However, in all cases where the IV estimate disagrees with the bias corrected OLS estimates, the former is always statistically insignificant.

In sum, our analysis confirms the importance of unobservables in evaluating the impact of Islamic school attendance. Studies that ignore unobserved factors such as degree of integration in school and student effort and/or exclusively rely on OLS estimators are likely to provide misleading policy conclusions. Naïve estimates of Islamic school attendance overestimate the associated learning disadvantage. The level of learning in rural secondary education in Bangladesh is low irrespective of school type so that both state registered schools and madrasahs should be targeted for quality improvement. This finding is consistent with emerging evidence on student learning in low income countries including those with/without a large Islamic schooling sector (Pritchett, 2004; Beatty and Pritchett, 2012). ${ }^{16}$

\section{Conclusion}

The evidence presented in this paper constitutes by far the most detailed account of the cognitive achievement in registered secondary madrasahs in Bangladesh. We find that registered madrasahs fare worse than their non-madrasah school counterparts, particularly in English. The gender gap in learning outcomes is also most pronounced in madrasahs. Thus, while registered madrasahs have played an instrumental role in reducing gender inequality in

\footnotetext{
16 Greaney et al. (1998) also confirm low level of basic competency amongst primary school completers in Bangladesh. In a revisionist study, Asadullah and Chaudhury (2013) build on Greaney et al. and confirm that the level of learning is very low across all primary school types in Bangladesh even when assessed in terms of rudimentary mathematics knowledge. This finding is consistent with emerging evidence from other countries in South Asia (Goyal, 2007a, 2007b; Das and Zajonc, 2010; Das, Pandey, and Zajonc, 2012).
} 
access, they need to address the issue of gender inequality in learning. OLS regression estimates confirm that even after controlling for the child's age, gender and family background, the madrasah penalty remains substantive and significant in English and maths. However, the size of the penalty is modest. More importantly, we show that OLS estimates are downward biased. Taking into account the potential bias, the point estimate becomes close to zero suggesting no substantive difference in maths test score across students of madrasahs and schools. Moreover, evidence also suggests that madrasah students appear to perform better in Religion test than their peers in non-madrasah schools. These findings suggest that it is difficult to conclude if madrasahs systematically offer a lower quality education relative to non-madrasah school from the students and their parents' point of view. If anything, there appears to be a trade-off in terms of education quality between English and religion. At the same time, overall quality is low across the board. The mean test score in mathematics is only marginally better than the scores that would have obtained through random guesswork. This also implies that the current focus on increasing the local supply of non-madrasah schools (assuming that places in these schools are rationed) to abate the demand for madrasah education and improve access to quality education is unlikely to be effective. However, quality gap between non-madrasah schools and state-registered madrasahs may still be large in urban areas. Equally, learning outcomes in unregistered madrasahs (i.e. those outside the state sector) remains unknown. Because of incomparable curriculum structure of unregistered madrasahs, it is difficult to comment on the quality of education measured in terms of test scores. These questions are left out for future research. 


\section{Reference}

Akerlof, George A. \& Rachel E. Kranton (2002) “Identity and Schooling: Some Lessons for the Economics of Education,” Journal of Economic Literature, 40(4): 1167-1201.

Altonji, J., T. Elder and C. Taber (2005a) “An Evaluation of Instrumental Variable Strategies for Estimating the Effects of Catholic Schools,” Journal of Human Resources, 4: 791821.

Altonji, G., T. Elder and C. Taber (2005b) "Selection on Observed and Unobserved Variables: Assessing the Effectiveness of Catholic Schools,” Journal of Political Economy, 113(1): 151-184.

Asadullah, M. Niaz (2009), "Returns to Private and Public Education in Bangladesh and Pakistan: A Comparative Analysis,” Journal of Asian Economics, 20(1): 77-86.

Asadullah, M Niaz and Chaudhury, N. (2009) "Holy Alliances: Public Subsidies, Islamic High Schools, and Female Schooling in Bangladesh,” Education Economics, 17(3): 377-394.

Asadullah, M Niaz and Chaudhury, N. (2013) "Primary Schooling, School Quality and Student Learning,” CGD Working Paper 349. Washington DC: Center for Global Development.

Asadullah, M Niaz and Chaudhury, N. (Forthcoming) "Islamic School Enrolment in Bangladesh: Evidence from Household Survey Data," Comparative Education Review.

Asadullah, M. Niaz and Chaudhury, N. and Dar, A. (2007) "Student Achievement Conditioned Upon School Selection: Religious and Secular Secondary School Quality in Bangladesh,” Economics of Education Review, 26(6): 648-659.

Asadullah, M Niaz, Chakrabarti, Rupa and Chaudhury, Nazmul (Forthcoming) "What Determines Religious School Choice? Theory and Evidence from Bangladesh,” Bulletin of Economic Research. DOI: 10.1111/j.1467-8586.2012.00476.x

Beatty, Amanda and Pritchett, Lant (2012) "From Schooling Goals to Learning Goals: How Fast Can Student Learning Improve?” CGD Policy Paper 012. Washington DC: Center for Global Development. 
Bachelard, Michael (2012) “Indonesia's Jihad Factories: Uncovering Nurseries of Terrorism's Next Generation,” The Sydney Morning Herald, October 7.

Das, Jishnu, Pandey, P. and Zajonc, T. (2012) "Learning Levels and Gaps in Pakistan: A Comparison with Uttar Pradesh and Madhya Pradesh,” Economic and Political Weekly, XLVII (26-27).

Das, Jishnu and Tristan Zajonc (2010) "India Shining and Bharat Drowning: Comparing Two Indian States to the Worldwide Distribution in Mathematics Achievement,” Journal of Development Economics, 92(2): 175-187.

Elder, Todd, and Christopher Jepsen (2014) “Are Catholic Primary Schools More Effective than Public Primary Schools?” Journal of Urban Economics, 80: 28-38.

Evans, W. and R. Schwab (1995) "Finishing High School and Starting College: Do Catholic Schools Make a Difference?” Quarterly Journal of Economics, 110: 941-974.

Gihleb, Rania \& Giuntella, Osea (2013) "Nuns and the Effects of Catholic Schools: Evidence from Vatican II,” IZA Discussion Papers 7753, Institute for the Study of Labor (IZA).

Griswold, Eliza (2005) "The Next Islamist Revolution?" January 23, New York Times; Magazine Desk.

Greaney, V., Khandker, S. R., and Alam, M. (1998) "Bangladesh: Assessing Basic Learning Skills”. The World Bank.

Goyal, Sangeeta (2007a) “Learning Achievements in India: A Study of Primary Education in Rajasthan,” The World Bank.

Goyal, Sangeeta (2007b) "Learning Achievements in India: A Study of Primary Education in Orissa,” The World Bank.

Hanushek, E. (2003) “The Failure of Input-based School Policies,” Economic Journal, 113, F64-98.

Hanushek, E. and Ludger Woessmann (2008) "The Role of Cognitive Skills in Economic Development,” Journal of Economic Literature, 46(3): 607-68.

Hwang, Julie Chernov (2012) “Terrorism in Perspective: An Assessment of "Jihad Project” Trends in Indonesia,” AsiaPacific Issues No. 104. Honolulu: East-West Center. 
Jepsen, C. (2003) “The Effectiveness of Catholic Primary Schooling,” Journal of Human Resources, 38: 928-941.

McEwan, Patrick J. (2001) “The Effectiveness of Public, Catholic, and Non-Religious Private Schools in Chile's Voucher System,” Education Economics, 9(2): 103-128.

Neighbour, Sally (2004) In the Shadow of Swords: On the Trail of Terrorism from Afghanistan to Australia. Sydney: HarperCollins Australia.

Newhouse, D., and Beegle, K. (2006) "The Effect of School Type on Academic Achievement: Evidence from Indonesia,” Journal of Human Resources, 41(3): 529-557.

Neal, D. (1997) "The Effects of Catholic Secondary Schooling on Educational Achievement,” Journal of Labour Economics, 15: 98-123.

Prais, S., (2005) “The Superior Educational Attainments of Pupils in Religious Foundation Schools in England,” National Institute Economic Review, 193: 102-105.

Pritchett, Lant (2004) “Access to Education.” In Global Crises, Global Solutions, edited by Björn Lomborg. Cambridge: Cambridge University Press.

Rosenberg, M. (1979) Conceiving the self. Malabar, FI: Krieger Publishing Company.

Sander, W. (1996) “Catholic Grade Schools and Academic Achievement,” Journal of Human Resources, 31: 540-548.

Sachar, Rajindar (2006) "Social, Economic and Educational Status of the Muslim Community of India: A Report”, Prime Minister’s High Level Committee Cabinet Secretariat Government of India.

Silva, Olmo and Gibbons, Stephen (2011) "Faith Primary Schools: Better Schools or Better Pupils?” Journal of Labor Economics, 29 (3): 589-635.

Wodon, Quentin (2013) "Faith-inspired, Private Secular, and Public Schools in Sub-Saharan Africa: Market Share, Reach to the Poor, Cost, and Satisfaction”, MPRA Paper 45363, University Library of Munich, Germany.

World Bank (2010) “Secondary School Madrasas in Bangladesh: Incidence, Quality, and Implications for Reform”, Bangladesh Development Studies (BDS) Series no 27. 
Appendix Table 1: Summary stats of school and teacher characteristics by school type

\begin{tabular}{|c|c|c|}
\hline & School & Madrasah \\
\hline \multicolumn{3}{|l|}{ School attributes } \\
\hline School : Government & 0.02 & \\
\hline : Non-government; unaided & 0.08 & \\
\hline : Non-government; aided & 0.90 & \\
\hline Madrasah: Non-government; unaided & & 0.15 \\
\hline : Non-government; aided & & 0.85 \\
\hline $\log ($ school land $)$ & 4.88 & 4.77 \\
\hline School has cell phone & 0.31 & 0.25 \\
\hline $\log (\#$ of rooms in school) & 2.61 & 2.70 \\
\hline $\operatorname{Ln}($ fees in tot) & 4.96 & 4.20 \\
\hline Class size & 59 & 39 \\
\hline Co-educational (fraction) & 0.83 & 0.80 \\
\hline Female dress code (full body cover) & 0.01 & 0.69 \\
\hline Residential - fully (partly) & 0 & $0.33(0.87)$ \\
\hline Sits on bench/chair in classroom & 1.00 & 1.00 \\
\hline No maths in grade 8 (fraction) & 0 & 0 \\
\hline No English in grade 8 (fraction) & 0 & 0 \\
\hline \multicolumn{3}{|l|}{ Average teacher } \\
\hline Fraction of female teachers & 0.18 & 0.09 \\
\hline Fraction of trained teachers & 0.69 & 0.25 \\
\hline Fraction of temporary teachers & 0.06 & 0.03 \\
\hline Teacher salary in Tk (in US \$) & $5856.34(86.12)$ & $4789.61(70.43)$ \\
\hline log(mean teacher salary) & 8.63 & 8.37 \\
\hline Salary data missing & 0.04 & 0.04 \\
\hline Total years of education & 14 & 16 \\
\hline Any religious education & 0.10 & 0.59 \\
\hline \multicolumn{3}{|l|}{ Maths teacher } \\
\hline Fraction of teachers being female & 0.08 & 0.06 \\
\hline Fraction of teachers being w/o training & 0.09 & 0.37 \\
\hline Fraction of teachers being Hindu & 0.26 & 0.03 \\
\hline Teaching experience (in years) & 14.58 & 10.42 \\
\hline Total years of education & 14.09 & 13.97 \\
\hline Household asset index & 0.28 & -0.05 \\
\hline Preparation (log of hours) & 2.24 & 2.32 \\
\hline \multicolumn{3}{|l|}{ English teacher } \\
\hline Proportion of teachers being female & 0.22 & 0.13 \\
\hline Proportion of teachers w/o training & 0.16 & 0.42 \\
\hline Proportion of teachers being Hindu & 0.17 & 0.05 \\
\hline Teaching experience (in years) & 13.21 & 12.63 \\
\hline Total years of education & 14.17 & 13.99 \\
\hline Household asset index & 0.23 & -0.03 \\
\hline Preparation (log of hours) & 2.25 & 2.28 \\
\hline $\mathrm{N}$ & 206 & 123 \\
\hline
\end{tabular}


Appendix Table 2: Summary stats of teacher evaluation of student behavior

\begin{tabular}{lcccc}
\hline & \multicolumn{3}{c}{ Mathematics } & English \\
\cline { 2 - 5 } & School & Madrasah & School & Madrasah \\
\cline { 2 - 5 } Perform below merit & 0.38 & 0.39 & 0.37 & 0.37 \\
Homework incomplete & 0.31 & 0.32 & 0.30 & 0.32 \\
Frequently absent & 0.29 & 0.33 & 0.30 & 0.30 \\
Late coming to class & 0.24 & 0.23 & 0.22 & 0.21 \\
Inattentive & 0.27 & 0.23 & 0.25 & 0.22 \\
Passive/withdrawn & 0.26 & 0.19 & 0.25 & 0.19 \\
Disruptive & 0.12 & 0.06 & 0.09 & 0.04 \\
\hline
\end{tabular}

Note: Each variable takes a value 1 if the teacher answers affirmatively and 0 otherwise. 
Appendix Figure 1: Kernel density of raw and normalized Mathematics and English test scores
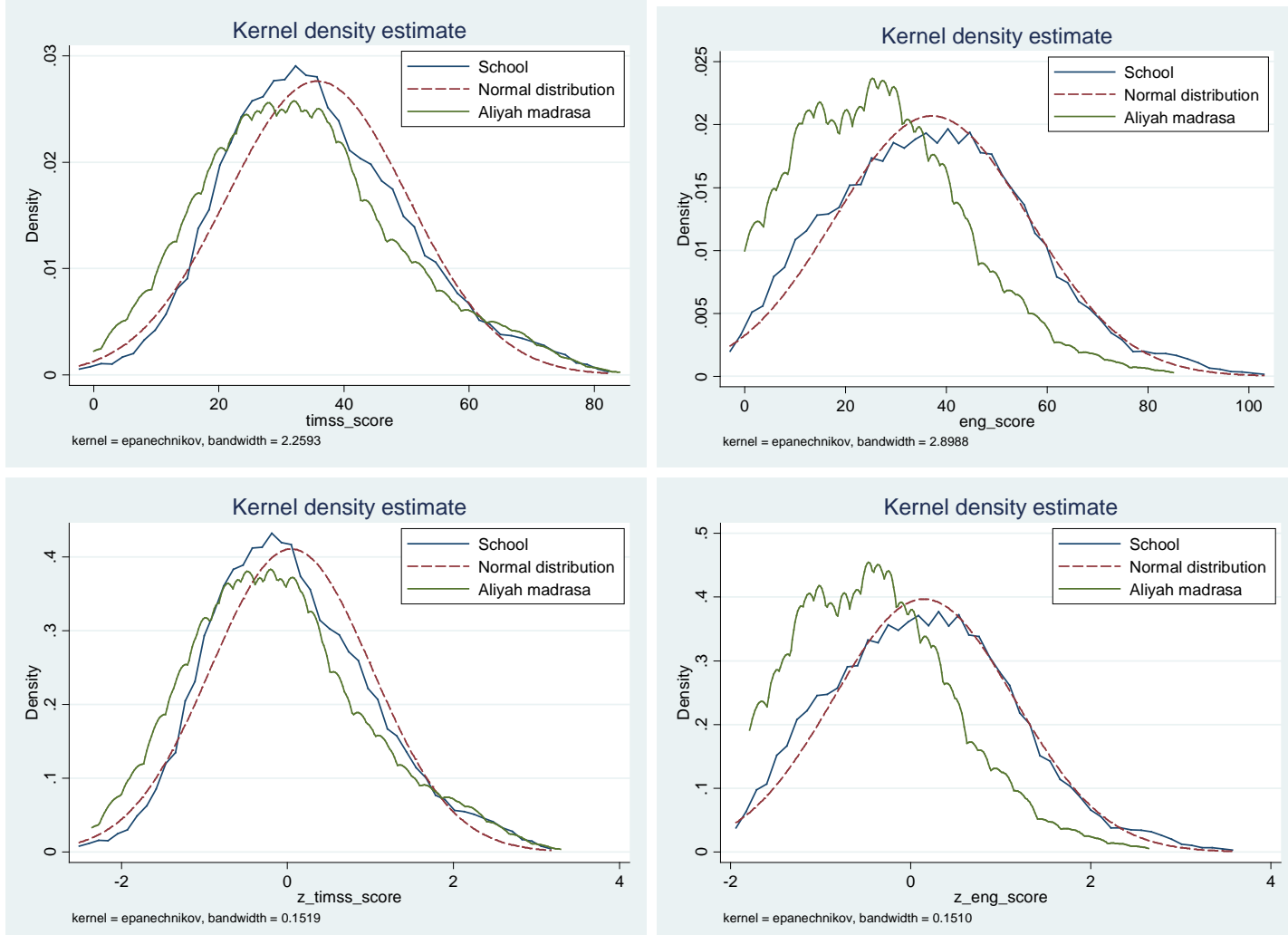